\title{
Towards Methanol Economy: A Techno-environmental Assessment for a Bio-methanol OFMSW/Biomass/Carbon Capture-based Integrated Plant
}

\author{
Aristide Giuliano, Enrico Catizzone*, Donatella Barisano, Francesco Nanna, Antonio Villone, Isabella De Bari, Giacinto \\ Cornacchia, Giacobbe Braccio
}

ENEA-Italian National Agency for New Technologies, Energy and Sustainable Economic Development, Trisaia Research Centre, I-75026, Rotondella, Italy

Corresponding Author Email: enrico.catizzone@enea.it

https://doi.org/10.18280/ijht.370301

Received: 29 June 2019

Accepted: 28 July 2019

\section{Keywords:}

CCUS, bio-methanol, bio-methane, biomass gasification, anaerobic digestion, renewable energy

\begin{abstract}
The anaerobic digestion (AD) of organic fraction municipal solid wastes (OFMSW) is a well-known technology for the valorization of wastes with the production of biogas, the latter usually used in power plant. Nevertheless, more and more effort is necessary in order to produce energy and chemicals from renewables as a strategy for replacing fossil fuels and reducing carbon dioxide in the atmosphere. In particular, methanol is considered as a promising energetic vector of the future since it may be produced from renewables and it may be used as a reactant for fuels and chemical production. Currently, methanol is industrially produced via syngas conversion using natural gas as the main feedstock. Biomethane produced in $\mathrm{AD}$ unit may be used as an alternative to natural gas for production of syngas that may be used for methanol production. In this work, a techno-environmental assessment for methanol production from biogas is presented and discussed, with focusing on the effect of side-unit, e.g. biomass gasification, carbon dioxide capture and renewable hydrogen production, on the environmental impact. Results show that highest $\mathrm{CO}_{2}$ saving is calculated for the biomass-integrated plant, although more detailed investigations, e.g. cost analysis, need for a proper assessment.
\end{abstract}

\section{INTRODUCTION}

Realizing a resource-efficient and sustainable energy economy is a current major challenge for worldwide society and chemical industry plays a key role to achieve this goal. The introduction of renewable energy in the chemical production chain is a key element to reduce the carbon and environmental footprint. In this concern, methanol may be considered as a suitable protagonist of this strategy, as reported elsewhere [1, 2]. Methanol may be used as a building block for the synthesis of several high-added values products, by both traditional process of industrial chemistry, e.g. acetic acid, methyl tert-butyl ether (MTBE), and emerging technologies, e.g. methanol-to-hydrocarbon and methanol-to-dimethyl ether processes [3-8].

Methanol is usually produced from syngas (a mixture of $\mathrm{H}_{2}, \mathrm{CO}$ and $\mathrm{CO}_{2}$ ) though the following reactions:

$$
\begin{array}{cc}
\mathrm{CO}+2 \mathrm{H}_{2}=\mathrm{CH}_{3} \mathrm{OH} & \Delta \mathrm{H}_{298 \mathrm{~K}}=-90.55 \mathrm{~kJ} / \mathrm{mol}_{\mathrm{CH} 3 \mathrm{OH}} \\
\mathrm{CO}_{2}+3 \mathrm{H}_{2}=\mathrm{CH}_{3} \mathrm{OH}+\mathrm{H}_{2} \mathrm{O} & \Delta \mathrm{H}_{298 \mathrm{~K}}=-49.43 \mathrm{~kJ} / \mathrm{mol}_{\mathrm{CH} 3 \mathrm{OH}} \\
\mathrm{CO}_{2}+\mathrm{H}_{2}=\mathrm{CO}+\mathrm{H}_{2} \mathrm{O} & \Delta \mathrm{H}_{298 \mathrm{~K}}=+41.12 \mathrm{~kJ} / \mathrm{mol}
\end{array}
$$

In addition, undesired side reactions such as methanation and coke formation also take place. Currently, the annual production of methanol is about 40 million tons per year and it continues to grow by $4 \%$ per year. The syngas required from the process is produced via reforming of fossil carbon sources, such as coal, oil or natural gas, with the latter as the main raw material. Concerning carbon dioxide emission, the coal-based plant has the highest carbon footprint, while when natural gas is used, lower $\mathrm{CO}_{2}$ amount is emitted. Steam reforming of methane is the most commercialized and wellknown technology for producing syngas. Although the huge amount of energy required from the process, steam reforming produces syngas with high hydrogen content, suitable for several industrial applications, such as methanol or ammonia synthesis.

Due to the growing carbon dioxide emissions and fossil fuel depletion that are causing significant environmental issues, alternative carbon sources should be considered in the light of a sustainable energy economy [8-20]. In this concern, biomass is considered an attractive low carbon source for various energy or chemical options due to its potentially low greenhouse gas emission. In this regard, biomass gasification (BG) may be used as a suitable technology to produce syngas. Gasification is a thermochemical process run at substoichiometric oxygen ratio able to convert solid fuel, such as biomass, in a gaseous stream that can be used for combined heat and power production, or as intermediate for chemicals production.

On the other hand, the syngas produced from BG has a hydrogen content too low for methanol synthesis; in fact the $\left(\mathrm{H}_{2}-\mathrm{CO}_{2}\right) /\left(\mathrm{CO}+\mathrm{CO}_{2}\right)$ molar ratio $(\mathrm{R})$ needed for the methanol synthesis should be at least 2 , and several steps have to be developed in order to increase the hydrogen content (e.g. gas clean-up, water gas shift, etc.) [17].

On the other side, biogas produces by anaerobic digestion of organic wastes represents an attractive renewable carbon 
source from both economic and environmental point of view $[21,22]$. In fact, AD unit produces biogas that is a mixture of methane and carbon dioxide $\left(\mathrm{CH}_{4} / \mathrm{CO}_{2}\right.$ molar ratio ranges from 1.1 to about 2.5) with minor quantities of nitrogen, hydrogen sulfide and volatile organic compounds. Biogas may be used as fuel in internal combustion engines although several technical/environmental concerns are involved. Emerging technologies provide a biogas upgrading system to obtain high-pure bio-methane that may be used as automotive fuel [23]. That bio-methane may be used as an alternative to fossil-methane (e.g., natural gas) for the production of syngas by reforming processes, such as dry reforming, steam reforming, partial oxidation or their combination (e.g. autothermal reforming, trireforming) [24]. As mentioned above, steam reforming is the used technology for syngas production.

Beside conventional routes, methanol may be alternatively produced via carbon dioxide hydrogenation, as long as hydrogen is produced via electrolysis of water by using renewables as an energy source, e.g., sunlight, wind, tides, etc., $[25,26]$. This is an attractive strategy to store energy and carbon dioxide in a high-added liquid like methanol.

This work aims to give new insights and revise the results presented by Giuliano et al. [1]. In particular, three different scenarios for bio-methanol production are assessed involving anaerobic digestion as a master unit coupled with side technologies as biomass gasification, carbon capture and water electrolysis, with the scope to give new perspectives for energy savings and greenhouse gas emission mitigation for methanol production, being methanol a candidate as carrier of the future energy economy.

\section{METHODS}

In this section, the investigated process configurations and the methodologies are summarized.

\subsection{Anaerobic digestion for biogas production (AD)}

All of the investigated cases are assessed by taking as calculation base an anaerobic digestion unit able to treat 10 tonnes/h of OFMSW. In particular, the characteristics of AD plant are based on the studies of Migliori et al. [25] and Li et al. [26] and it was not included in the process simulation but was considered for environmental aspects. In particular, it was considered that $\mathrm{AD}$ unit is a horizontal dry-type reactor that is continuously fed with the pulp of OFMSW with about $27 \mathrm{wt} \%$ of solid content keeping a residence time of about one month under mesophilic conditions (about $40{ }^{\circ} \mathrm{C}$ ). According to the previously cited studies, the biogas out coming from the reactor is a mixture containing methane and carbon dioxide as main components, and contaminants such as hydrogen sulfide and volatile organic compounds. It is assumed that the raw biogas is treated with an upgrading system consisting of chemical scrubbers, active carbon filters and membranes able to completely remove contaminants obtaining highly purified bio-methane [24, 25]. Biogas purification is a crucial step since contaminants may deactivate the catalysts used for the successive units. Based on data reported in the literature [26], the production of biomethane from the above-described process should be about $500 \mathrm{Nm}^{3} / \mathrm{h}$. Digestate is assumed to be used for agricultural uses after the composting step.

\subsection{Biomass gasification (BG)}

The characteristics and performances of biomass gasification units were assumed to be similar to those reported by Barisano et al. [27]. In brief, Barisano et al. [27] report a study about a pilot-scale internally circulating bubbling fluidized bed reactor using almond shells as biomass feedstock. Briefly, biomass is gasified at atmospheric pressure and $820-880{ }^{\circ} \mathrm{C}$ by using steam $/ \mathrm{O}_{2}$ mixture as gasification agent. Both char and tar present in the reactor out-stream are abated with ceramic filter and wet scrubber, respectively. The gas stream from the gasification unit is assumed to be cleaned from residual tars and sulfur compounds obtaining a mixture with the average composition reported in Table 1:

Table 1. Composition of the bio-syngas stream of gasification unit (\% $\%$ vol $_{\text {DRY }}$ )

\begin{tabular}{ccccc}
\hline $\mathrm{CO}$ & $\mathrm{H}_{2}$ & $\mathrm{CO}_{2}$ & $\mathrm{CH}_{4}$ & $\mathrm{~N}_{2}$ \\
\hline 28 & 32 & 25 & 10 & 5 \\
\hline
\end{tabular}

\subsection{Process description for methanol production}

As previously reported, syngas with a $\mathrm{H}_{2} / \mathrm{CO}$ equals to about 3, suitable for methanol synthesis, may be produced via steam reforming of bio-methane (BM) produced via anaerobic digestion. Nevertheless, both practical and theoretical evidence suggest that a $\mathrm{R}$ value as low as 2 may be considered optimal for methanol synthesis [31]. Therefore in this work three different scenarios for bio-methanol production are investigated. In particular, steam reforming of bio-methane was coupled to three different processes in order to obtain the optimal $\mathrm{R}$ value required for methanol synthesis, with the main scope to reduce $\mathrm{CO}_{2}$ emission. In particular, the following three cases were assessed:

Case 1- Steam reforming of bio-methane (BM-SR) coupled to a biomass gasification unit with characteristics similar to those reported in Ref. [29]. In particular, biomass gasification produces syngas with a low $\mathrm{R}$ value (lower than 1) not suitable for methanol synthesis. Such hydrogen-poor syngas stream is mixed with hydrogen-rich syngas produced via biomethane reformed syngas (BM-SR) aiming to obtain the optimal $\mathrm{R}$ value (i.e., 2). A scheme of the process is reported in Figure 1.

Case 2- BM-SR with partial utilization of $\mathrm{CO}_{2}$ produced from anaerobic digestion $\left(\mathrm{AD}-\mathrm{CO}_{2}\right)$. As reported below, carbon dioxide may also be used as carbon source for methanol synthesis; therefore the $\mathrm{CO}_{2}$ produced from OFMSW anaerobic digestion was captured and added to BM-SR stream to obtain the optimal $\mathrm{R}$ value. A scheme of the process is reported in Figure 2.

Case 3- BM-SR with total utilization of $\mathrm{AD}-\mathrm{CO}_{2}$. By using all of the $\mathrm{AD}-\mathrm{CO}_{2}$ for methanol synthesis, hydrogen is requested in order to ensure a suitable $\mathrm{R}$ value. Therefore, in that case, water electrolysis was considered for the production of the required hydrogen to have the optimal $\mathrm{R}$ value for methanol synthesis. It was assumed that renewable energy (e.g., solar energy) is used for the electrolysis unit. A scheme of the process is reported in Figure 3. 
An alternative way to use the $\mathrm{CO}_{2}$ produced from $\mathrm{AD}$, may be the direct tri-reforming of biogas; furthermore, biomass gasification unit may be also involved in both Case 2 and Case 3 in order to convert the wastes that cannot be used in $\mathrm{AD}$ reactor (e.g. wood-type wastes) but these aspects are beyond the purpose of this work, that is to propose some strategies for bio-methanol production with a not-deep analysis of process details.

\subsection{Process simulation for methanol production}

To simulate different processes of section 2.3, the process simulation software CHEMCAD was used. Redlich-KwongSoave thermodynamic equation of state was adopted to simulate high-pressure systems, while NRTL-RK was used for distillation columns and flash separation units. Table 1 reports the main parameters adopted for the simulation.

\subsubsection{Production of syngas from OFMSW}

Biogas produced from anaerobic digestion of OFMSW was considered purified from any contaminant and having a molar $\mathrm{CH}_{4} / \mathrm{CO}_{2}$ ratio equals to 1.5 . High-pure methane was obtained via membrane separation that requires a biogas compression up to 12 bar (by an isoentropic compressor). This kind of technology is usually adopted for the production of methane for automotive.

The bio-methane was converted into syngas by steam reforming reaction (SR). For this purpose, it was considered to operate under equilibrium conditions at $850{ }^{\circ} \mathrm{C}$ and $30 \mathrm{bar}$ by assuming a weight steam-to-methane ratio in the reaction inlet equals to 3.4. As previously mentioned, steam reforming is an endothermic process and the required heat duty was produced by burning purge gas of the plant as depicted in Figure 1.

\subsubsection{Syngas from biomass}

Biomass gasification data were obtained from experimental tests carried out by Barisano et al. [27]. BG was performed with an equivalence ratio equals to 0.2 by using pure oxygen $\left(312 \mathrm{~kg} 2 / \mathrm{t}_{\text {biomass }}\right)$ and steam $\left(440 \mathrm{~kg} / \mathrm{t}_{\text {biomass }}\right)$ as oxidant agents in the gasifier. The utilization of both oxygen and steam allows having a quasi-autothermal process. Furthermore, pure oxygen is preferred to air is syngas with low nitrogen content is desired. High nitrogen content, e.g. producer gas, would be not suitable for the investigated catalytic application, i.e. methanol synthesis, since it would require high compression power and large reactor volume due to the dilutive effect of nitrogen. One of the aims of the experimental work carried out by Barisano et al. [27] was exactly to obtain a syngas suitable (after proper composition adjustment) for the conversion into gaseous or liquid secondary energy carries including methanol. Moreover, it is important to highlight that the operability of a biomass gasification reactor strongly depends on biomass type also. For instance, biomass with a high amount of ashes or a notwell controlled temperature may cause several problems to the system, e.g. ash melting, high tars condensation rate.

In the simulation, it was assumed that bio-syngas leaves the gasifier at about $750{ }^{\circ} \mathrm{C}$ and atmospheric pressure. Also in this case, it was assumed that syngas is efficiently upgraded obtaining a clean stream with the composition reported in Table 1.

\subsection{3 $\mathrm{MeOH}$ production}

As discussed in the introduction part, in the methanol synthesis reactor the conversion of syngas into raw methanol takes place. The raw methanol coming out from the reactor is a mixture of methanol, water, dissolved gases and byproducts such as dimethyl ether, higher alcohols and other oxygenated, e.g. aldehydes. The heats of reaction reported in the introduction part reveal that methanol synthesis is favored at low temperature being an exothermic reaction. Furthermore, from a thermodynamic point of view, also high pressure promotes methanol synthesis. One of the main issue of methanol reactor is to control the temperature with an efficient removal of heat of reaction; in fact the reactor temperature has to be low enough both for thermodynamics advantages and for preventing catalyst sintering (a cause of deactivation), but, at the same time high enough in order to ensure high conversion per pass. Three different reactor type are usually used: quench, adiabatic and boiling water (BWR) reactor. A quench reactor consists of 4-5 adiabatic catalyst bed in series and the reactor feed (fresh and recycled syngas) is split into different fraction and used as quenching stream for each catalytic bed. A more used technology is the adiabatic reactor consisting of up to five adiabatic catalytic bed with intercoolers. Usually, water is used in the intercooler and medium pressure steam is generated. Quasiisothermal conditions are ensured by adopting BWR configuration that is a tube and shell heat exchanger in which the reaction takes place inside the tube and boiling water is circulated in the shell. Also in that case, medium steam may be generated and used as hot utility around the plant. Although a good temperature control, a high investment cost is requested for BWR configuration, therefore adiabatic reactor is usually preferred and that is adopted in our calculation. $\mathrm{Cu}-\mathrm{ZnO} /$ alumina is currently used as catalyst for methanol synthesis. Such kind of catalyst exhibits high selectivity and stability but it requires extremely pure syngas (i.e. larger free of sulfur of chlorine compounds, $<100 \mathrm{ppb}$ ).

Syngas stream obtained in the three different cases was compressed to $80 \mathrm{bar}$, mixed with recycle stream (unreacted syngas), cooled down to $200{ }^{\circ} \mathrm{C}$ and fed to the methanol synthesis adiabatic reactor. An equilibrium reactor was adopted for the methanol synthesis unit by considering the reactions reported in the introduction part. A pressure drop equal to 2 bar was assumed along the reactor.

\subsubsection{Recycle and $\mathrm{MeOH}$ purification}

As mentioned before, crude methanol leaving the reactor contains water and impurities (e.g. dissolved gases) that have to be removed. The amount and the type of such contaminants depend on the reaction conditions, syngas purity and catalyst lifetime. In this paper, it was assumed that no by-products, except water, are produced but it is important to underline that this aspect should be taken into account for a more detailed process assessment. For example, the alkaline solution is usually used in order to neutralize some carboxylic acids formed during the reaction, but this aspect is not considered in this study. In this study, the purification system separates incondensable species (i.e. $\mathrm{CO}_{2}, \mathrm{CO}$ and $\mathrm{H}_{2}$ ) and water from methanol. Therefore, reactor outstream was cooled to $40{ }^{\circ} \mathrm{C}$ and pre-purified in a flash phase-separator where light gases are separated and partially recycled. The purge stream was used as fuel for SR reactor while recycle stream was recompressed to 80 bar and mixed to fresh syngas stream. For this purpose, 2 bar compressed air with an excess 
of $100 \%$ respect to the stoichiometric amount was used. The liquid stream, mainly containing methanol and water, was expanded in a throttling valve until 2 bar and distilled to produce a $\mathrm{MeOH}$ rich stream from the top and wastewater from the bottom. The distillate was further purified in a flash phase-separator to obtain a $99 \% \mathrm{MeOH}$ stream. More details of the process simulation are reported in Table 2.

Table 2. Process simulation parameters

\begin{tabular}{|c|c|c|c|}
\hline $\begin{array}{l}\text { OFMSW flowrate } \\
(\mathrm{t} / \mathrm{h})\end{array}$ & 10 & $\begin{array}{l}\text { MeOH reactor pressure } \\
\text { (bar) }\end{array}$ & 80 \\
\hline $\begin{array}{c}\text { Biogas yield } \\
\text { (t/toFMSw) }\end{array}$ & 0.5 & $\begin{array}{l}\text { Biomethane membrane } \\
\text { temperature }\left({ }^{\circ} \mathrm{C}\right)\end{array}$ & 40 \\
\hline $\begin{array}{l}\text { Membrane } \\
\text { hiomethe recovy }\end{array}$ & & & \\
\hline $\begin{array}{l}\text { biomethane recovery } \\
(\%)\end{array}$ & 100 & SR temperature $\left({ }^{\circ} \mathrm{C}\right)$ & 850 \\
\hline $\begin{array}{c}\text { Biomethane purity } \\
(\%)\end{array}$ & 100 & $\begin{array}{l}\text { Biomass syngas } \\
\text { temperature }\left({ }^{\circ} \mathrm{C}\right)\end{array}$ & 750 \\
\hline $\begin{array}{l}\text { Steam to carbon ratio } \\
\quad \text { in } \mathrm{SR}\left(\mathrm{t}_{\mathrm{S}} / \mathrm{t}_{\mathrm{CH} 4}\right)\end{array}$ & 3.4 & $\begin{array}{l}\mathrm{MeOH} \text { reactor inlet } \\
\text { temperature }\left({ }^{\circ} \mathrm{C}\right)\end{array}$ & 200 \\
\hline $\begin{array}{c}\text { Biomass syngas yield } \\
(\mathrm{t} / \mathrm{tDRY})\end{array}$ & 1.07 & Columns pressure (bar) & 2 \\
\hline $\begin{array}{l}\text { Biomethane } \\
\text { membrane pressure } \\
\text { (bar) }\end{array}$ & 12 & $\begin{array}{l}\text { Recycle condenser } \\
\text { temperature }\left({ }^{\circ} \mathrm{C}\right)\end{array}$ & 40 \\
\hline SR pressure (bar) & 30 & $\begin{array}{l}\text { Stoichiometric ratio } \\
\text { air/purge }\end{array}$ & 2 \\
\hline
\end{tabular}

\subsection{Environmental impact analysis}

For each process case, a final environmental impact analysis was performed in terms of total $\mathrm{CO}_{2}$-equivalent emission by adopting the values reported in Table 3 . In particular, a negative $\mathrm{CO}_{2}$-equivalent emission value is associated with both biomass and OFMSW, by considering the $\mathrm{CO}_{2}$ absorbed from the atmosphere by biomass and the $\mathrm{CO}_{2}$ emitted from the landfill for organic waste disposal, respectively. In order to estimate the environmental impact of pure oxygen production, air separation unit (ASU) was supposed. A typical air separation unit plant produces the oxygen required for gasification, with a $85 \%$ purity by volume. Considering electricity (for the air compression) and thermal energy (for the air distillation) an environmental impact value in term of $\mathrm{CO}_{2}$-equivalent emission equal 282 $\mathrm{kg}_{\mathrm{CO} 2 \mathrm{eq}} / \mathrm{t}_{\mathrm{O} 2}$ to can be obtained [33], The environmental impact value for pure hydrogen production was considered for the case of water electrolysis using solar energy as a primary energy source [34]. This value is lower than $\mathrm{CO}_{2}$-equivalent emission producing pure hydrogen by natural gas, oil, coal, or other raw material, but also lower than impact by wind energy or geothermal energy. Supposing the photovoltaic technology as a process to produce pure hydrogen the impact is due only to the production of photovoltaic panels and to lands utilization. Process water utilization can have a low environmental impact, also considering detoxification and demineralization processes. Wastewater effluent can have an environmental impact corresponding to the purification process and the input of the purified water into rainwater collections. Finally, the electricity production impact was considered equal to that of the fossil-based energy production system.

Table 3. $\mathrm{CO}_{2}$-equivalent emission parameters

\begin{tabular}{cc}
\hline Process item & Set-up value \\
Electricity $\left(\mathrm{kgCO2eq}_{\mathrm{M}} / \mathrm{MWhe}\right)[30]$ & 600 \\
Biomass feedstock $\left(\mathrm{kg}_{\mathrm{CO} 2 \mathrm{eq}} / \mathrm{t}\right)[31]$ & -1449 \\
OFMSW $\left(\mathrm{kg}_{\mathrm{CO} 2 \mathrm{eq}} / \mathrm{t}\right)[32]$ & -1597 \\
Wastewater $\left(\mathrm{kg}_{\mathrm{CO} 2 \mathrm{eq}} / \mathrm{t}\right)[30]$ & 500 \\
Pure oxygen $\left(\mathrm{kg}_{\mathrm{CO} 2 \mathrm{eq}} / \mathrm{t}\right)[33]$ & 282 \\
Process water $\left(\mathrm{kg}_{\mathrm{CO} 2 \mathrm{eq}} / \mathrm{t}\right)[30]$ & 6.5 \\
Pure hydrogen $\left(\mathrm{kg}_{\mathrm{CO} \mathrm{eq}} / \mathrm{t}\right)[34]$ & 2400 \\
\hline
\end{tabular}

Furthermore, the environmental impact estimated for the investigated bio-methanol production plants was compared with the that associated with the production of methanol from fossils, that is about $915 \mathrm{~kg}_{\mathrm{CO} 2 \mathrm{eq}} / \mathrm{t}_{\mathrm{MeOH}}$ and $1600 \mathrm{~kg} \mathrm{CO}_{\mathrm{eq}} / \mathrm{t}_{\mathrm{MeOH}}$ when natural gas or coal as used as feedstock, respectively [34].

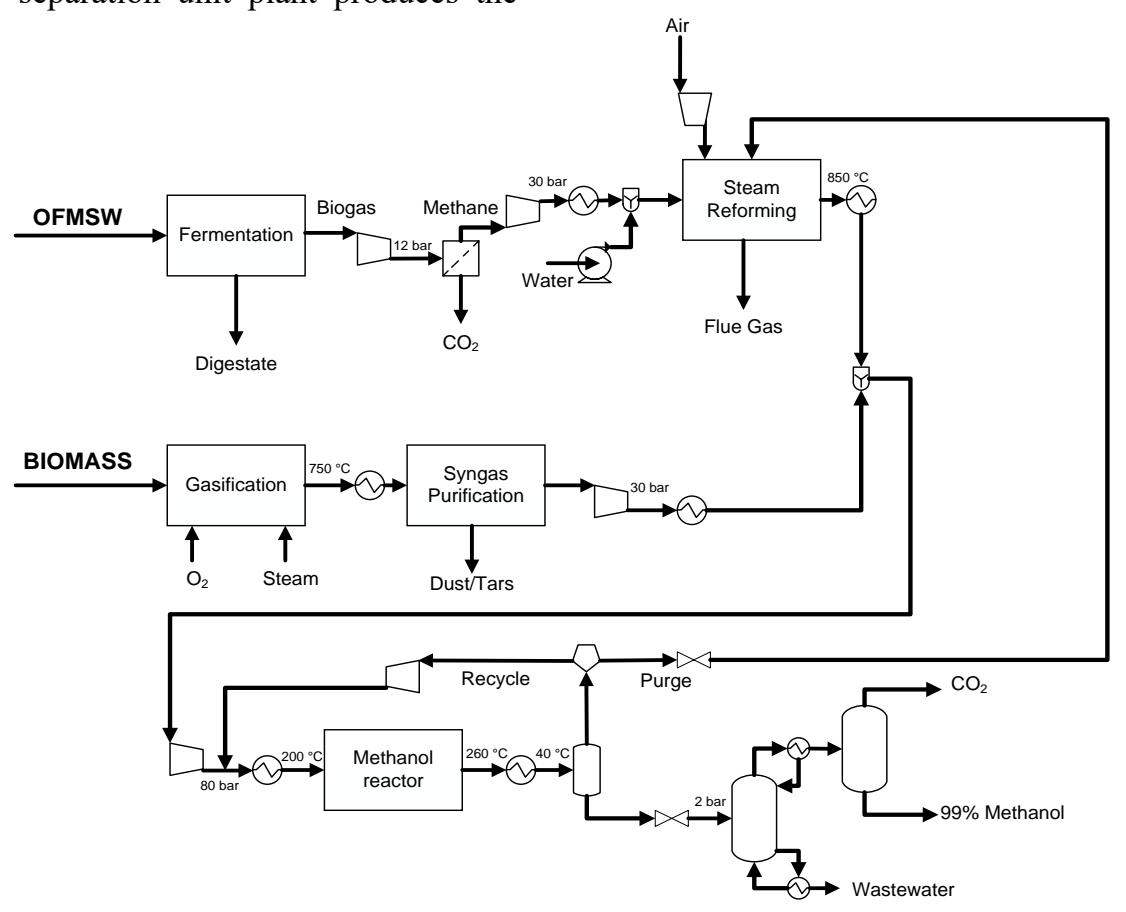

Figure 1. Process flowsheet for case 1: Bio-methanol production from an anaerobic digestion plant with steam reforming of biomethane coupled with a biomass gasification unit 


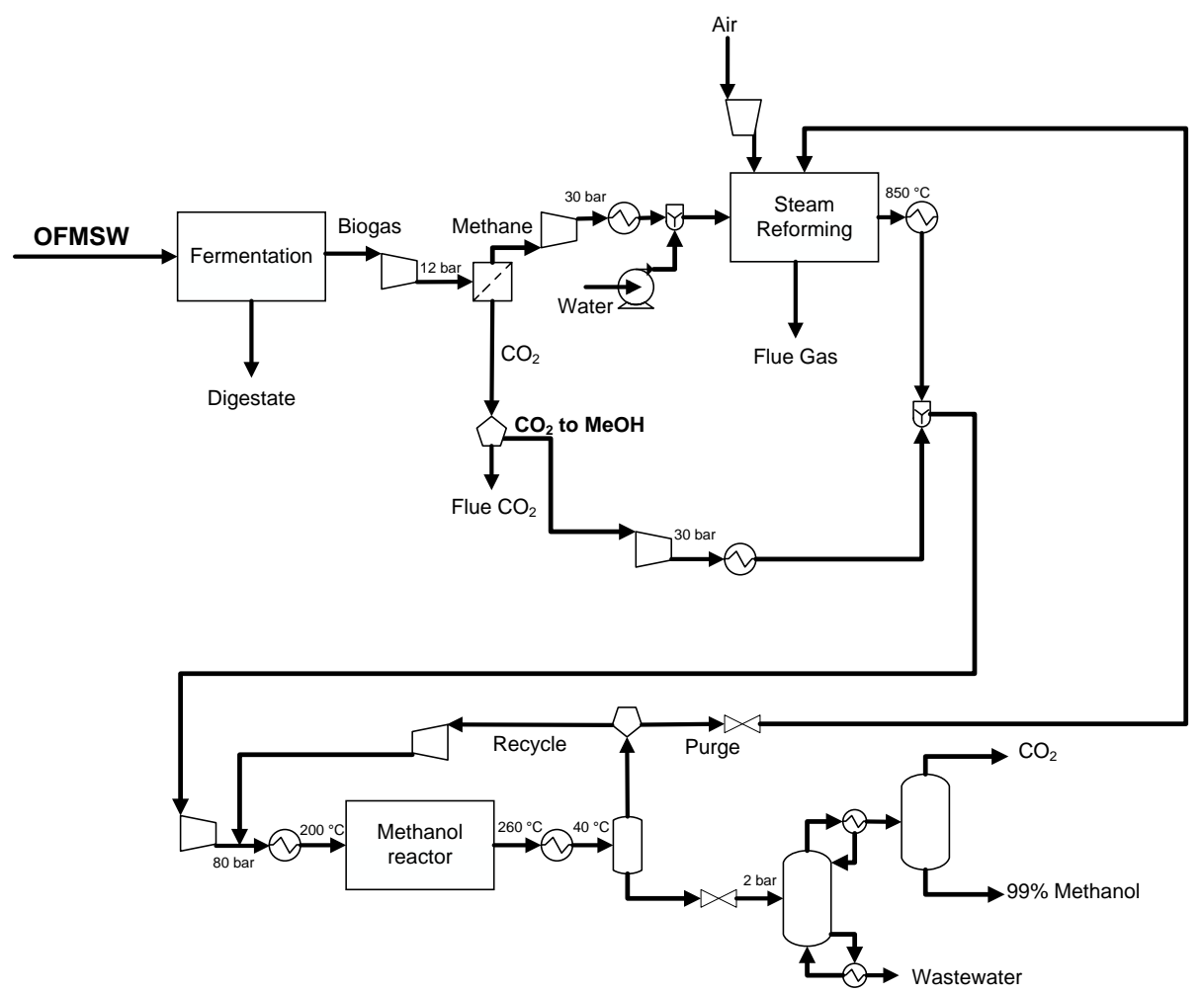

Figure 2. Process flowsheet for case 2: Bio-methanol production from an anaerobic digestion plant with steam reforming of biomethane with a partial reuse of carbon dioxide

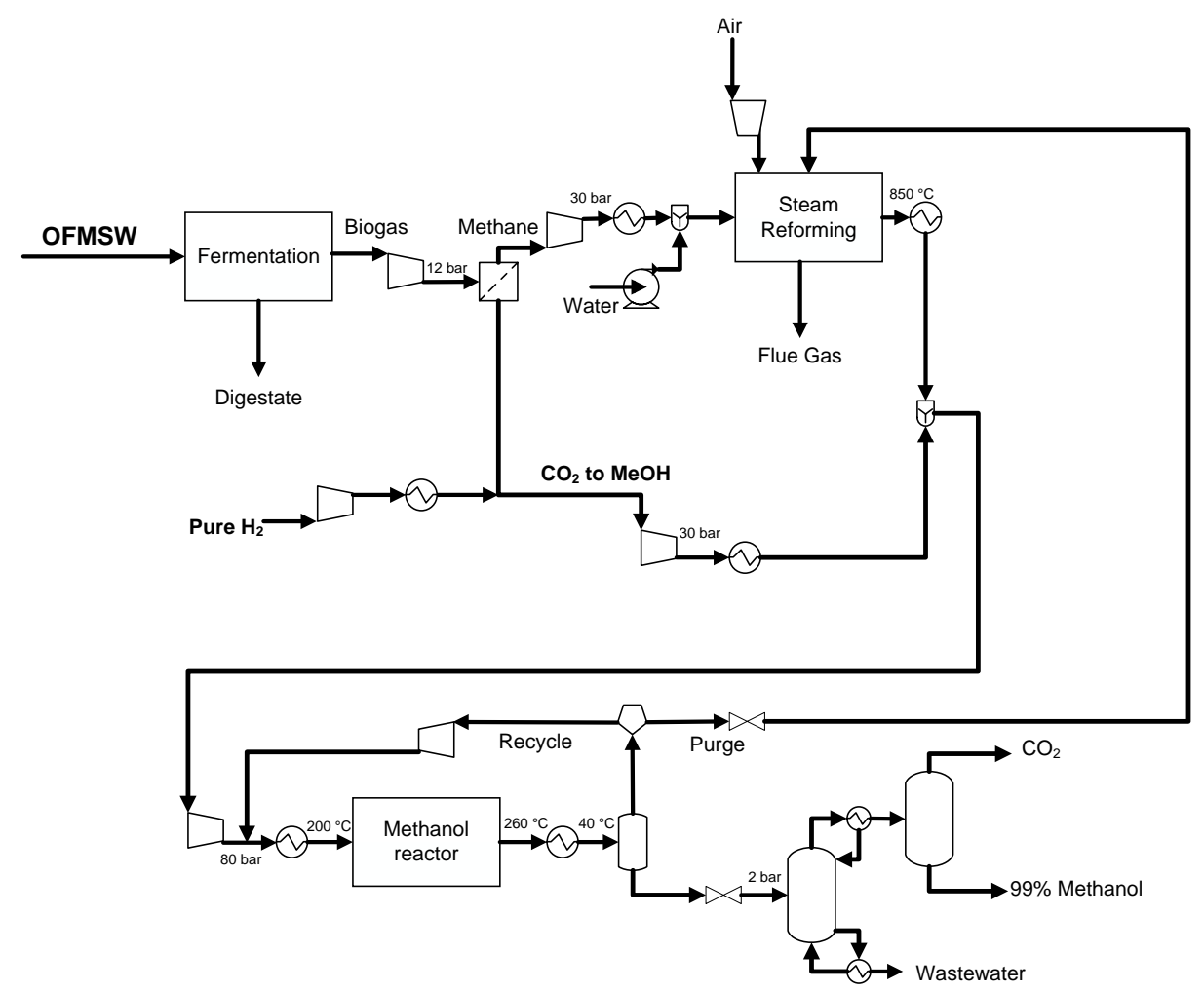

Figure 3. Process flowsheet for case 3: Bio-methanol production from an anaerobic digestion plant with steam reforming of biomethane with a total reuse of carbon dioxide and an renewables-based electrolysis unit for hydrogen production

\section{RESULTS}

In this paragraph and in Table 4 the main results of the three scenarios investigated are reported.

\subsection{Case 1}

Biomass flowrate strongly affects the methanol productivity due to the low hydrogen content into biosyngas. In fact, higher is the biomass flowrate lower is the hydrogen 
content in the reactor inlet. In fact, by increasing the biomass flow rate from 0 to 4 ton/h the $\mathrm{R}$ value decreases to 0.5 , causing a consequent drop in the theoretical methanol yield. Figure 4 shows the effect of biomass/OFMSW on methanol thermodynamic equilibrium yield calculated on carbon basis.

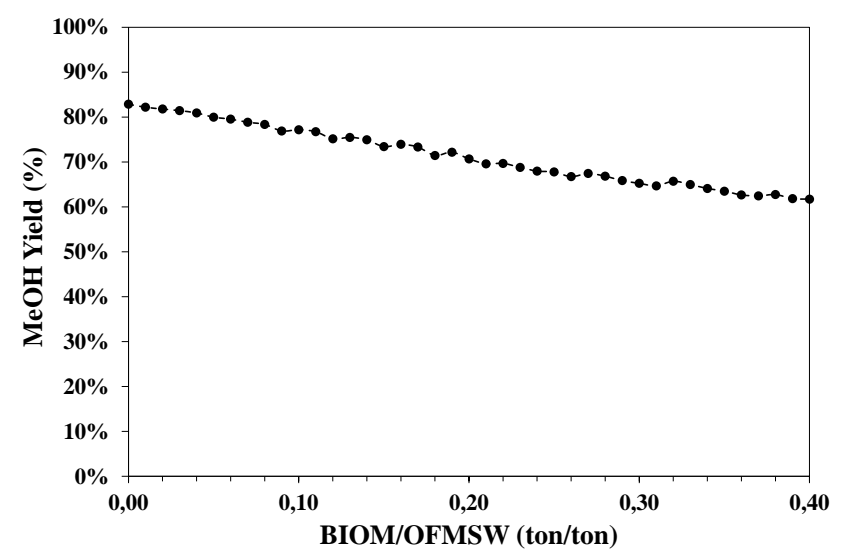

Figure 4. Methanol thermodynamic yield as a function of biomass/OFMSW ratio

Methanol thermodynamic yield $\left(\mathrm{Y}_{\mathrm{MeOH}}\right)$ linearly depends on biomass-to-OFMSW mass ratio. In particular, the following relation may be derived:

$$
\mathrm{Y}_{\mathrm{MeOH}}(\%)=82-55 \cdot(\mathrm{BIOM} / \mathrm{OFMSW})
$$

On the whole, the methanol productivity increases from about 2.8 to about $3.5 \mathrm{t} / \mathrm{h}$ by increasing the biomass-toOFMSW ratio from 0 to 0.4 .

Concerning the theoretical electrical demand, the biomass flowrate strongly affects the compression power since higher is the biomass flowrate and higher is the bio-syngas to be compressed at the methanol synthesis pressure. As reported in Figure 5, the compression increase due to gasification unit integration is about $1 \mathrm{MWe}$ when a biomass-to-OFMSW ratio equals to 0.4 is adopted. In fact, the total power demand increases from about $4 \mathrm{MWe}$ to about $5 \mathrm{MWe}$ if the biomass flowrate increases from 0 to 4 ton/h. On the other hand, as discussed before, the total methanol production increases when biomass is used. In this sense, the specific compression energy requirement is also calculated and reported in Figure 5 .

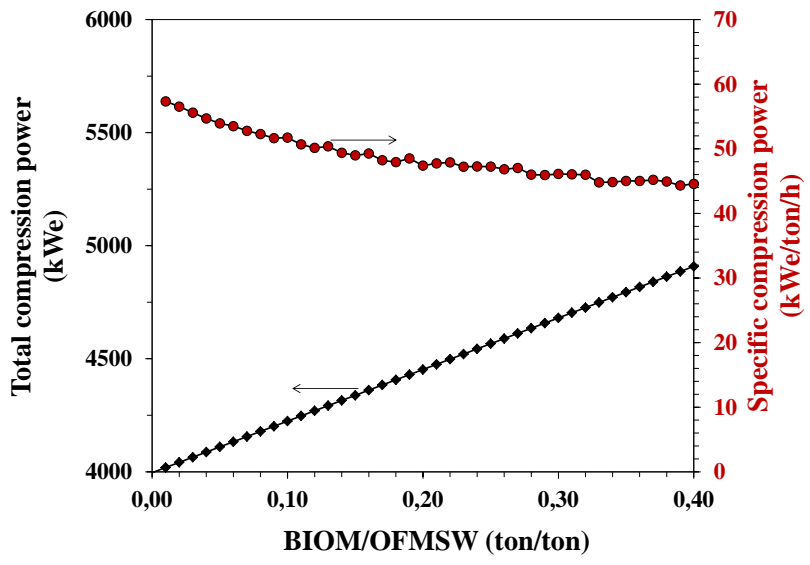

Figure 5. Total compression power (dx) and specific compression power (sx) as a function of biomass-to-OFMSW mass flowrate ratio
The trend clearly shows that higher is the biomass flowrate and lower is the specific compression work. In particular, this effect is more evident for low biomass inputs. In fact, by increasing the biomass flowrate from 0 to $2 \mathrm{t} / \mathrm{h}$ the specific compression power decreases from about 58 to about 48 $\mathrm{kWh} /$ ton, whilst is further reduced to about $45 \mathrm{kWh} /$ ton when the biomass flowrate is set to $4 \mathrm{t} / \mathrm{h}$. Of course, the energy requirement for biomass pretreatment is not taken into account is this study, although it is an important aspect to be considered for a proper techno-energetic analysis of a biomass-based plant.

On the whole, a biomass flowrate of about $1.9 \mathrm{t} / \mathrm{h}$ is calculated for an effective methanol production. In that conditions, the production of bio-methanol requires about 4.4 MWe, mainly related to compressors. In particular, biogas compressor until 12 bar $(0.5 \mathrm{MWe})$, biomass-syngas compressor until 30 bar $(0.5 \mathrm{MWe})$, the compressor of fresh feed of methanol reactor $(1.1 \mathrm{MWe})$ and SR furnace compressors $(2.2 \mathrm{MWe})$ were the main high-consumption equipments.

According to the experimental investigations of Barisano et al. [27] with an internally circulating bubbling fluidized bed reactor, the estimated bio-syngas productivity is about 2 $\mathrm{t} / \mathrm{h}$ with the composition reported in Table 1. Steamreforming of bio-methane produces about 9.7 ton/h of syngas with $\mathrm{R}=3$. By mixing such stream with the syngas produced from the gasification unit the $\mathrm{R}$ value is reduced to 2.8 . In the methanol reactor inlet a $R$ value equals to 2 is ensured by recycling stream.

Under such conditions, the outlet temperature of the methanol synthesis reactor was $267{ }^{\circ} \mathrm{C}$ with productivity of purified methanol of $3.06 \mathrm{t} / \mathrm{h}$. Theoretical methanol productivity might be improved by adopting alternative reactor configurations. For instance, as previously discussed, by using isothermal (e.g. BWR) or quenching reactor a lower reactor temperature favors the methanol production, from a thermodynamic point of view.

As discussed above, the purge stream from methanol reactor can be used as fuel in order to support the steamreforming reactor.

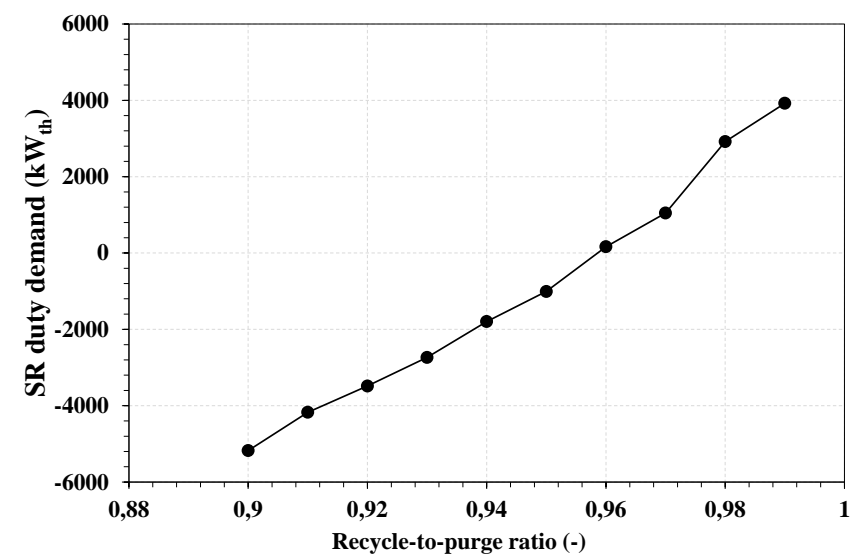

Figure 6. External duty demand for steam-reforming of biomethane as a function of recycle-to-purge ratio of methanol reactor

Figure 6 reports the effect of recycle-to-purge ratio (RP) on the external thermal energy demand for steam reforming reactor. Simulated data suggests that RP strongly affects the energy demand for steam reforming of bio-methane. Of 
course, higher is the RP value higher is the energy demand. It is important to note that for $\mathrm{RP}<0.96$ a negative value is calculated indicating that surplus of thermal energy is produced and that may be used for other plant units, such as steam or hot water production. On the contrary, for RP $>0.96$ a positive value is simulated, indicating that external thermal inputs have to be used. In that case, natural gas or also biomass might be used as fuel for heat production. On the whole, a $\mathrm{RP}=0.96$ allows having a low purge to recycle ratio (4\%) able to provide the thermal energy requested by steam reforming of bio-methane. On the other hand, higher is the recycle flowrate and higher is reactor inlet flowrate with a direct influence on total methanol productivity.

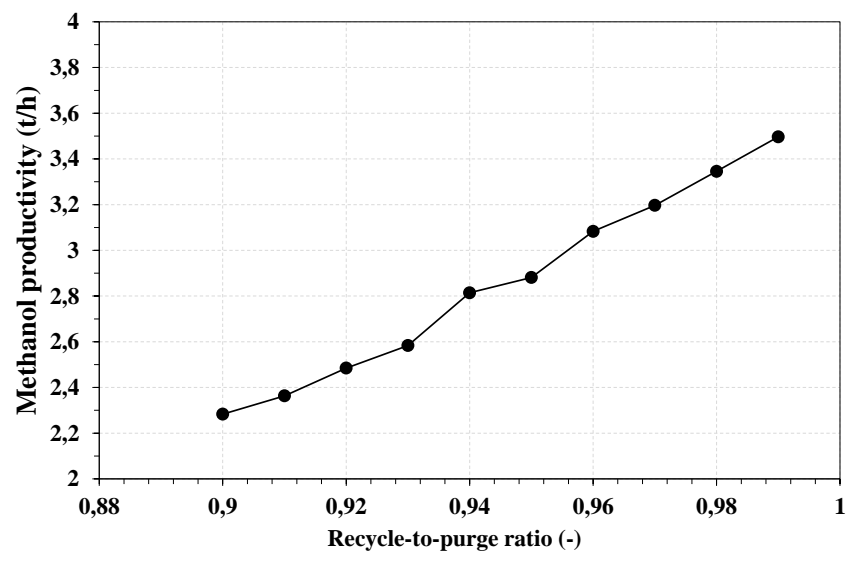

Figure 7. Total methanol productivity as a function of recycle-to-purge ratio of methanol reactor

As reported in Figure 7, the total methanol production increases from about $2.3 \mathrm{t} / \mathrm{h}$ to about $3.5 \mathrm{t} / \mathrm{h}$ by increasing the $\mathrm{PR}$ ratio from 0.9 to 0.99 . When the $\mathrm{RP}$ value is set to $0.96 \mathrm{a}$ total methanol productivity of about $3.1 \mathrm{t} / \mathrm{h}$ is calculated.

\subsection{Case 2}

As previously described, Case 2 deals with the partial reusing of carbon dioxide formed during anaerobic digestion process. The syngas produced via SR of bio-methane was enriched with about $1.3 \mathrm{t} / \mathrm{h}$ of $\mathrm{AD}-\mathrm{CO}_{2}$ that correspond to a carbon dioxide reuse equals to $40 \%$. In this way, a syngas stream with a $\mathrm{R}=2$ is obtained, a proper value for methanol synthesis. Under such conditions, about $2.3 \mathrm{t} / \mathrm{h}$ of purified methanol may be estimated. Furthermore, due to higher $\mathrm{CO}_{2}$ concentration, a lower LHV is calculated for purge stream respect to Case 1 . Therefore, a higher purge ratio, such as $7 \%$, is requested to thermally support the steam reforming reactor, causing a process efficiency loss.

Lower electricity consumption $(4.0 \mathrm{MWe})$ than in the previous case was obtained thanks to a lower reactor inlet flowrate to compress and the lack of syngas compressor. It is important to underline that kinetic aspects were not considered in this study. For instance, a high concentration of carbon dioxide in the methanol reactor might require a more active catalyst with specific catalytic properties [4].

\subsection{Case 3}

For case 3, all of the captured $\mathrm{AD}-\mathrm{CO}_{2}$ (about $3.2 \mathrm{t} / \mathrm{h}$ ) is used for methanol synthesis. In that case, as previously described, hydrogen has to be produced in order to ensure
$\mathrm{R}=2$ at the reactor inlet. Under such conditions, about $3.9 \mathrm{t} / \mathrm{h}$ of purified methanol is produced, mainly because of the high syngas flowrate available for the reaction. On the other hand, high electricity consumption was calculated for the compressor of fresh reactor feed (about 1.6 Mwe). Also the $\mathrm{CO}_{2}$ and pure hydrogen compressors (about $0.9 \mathrm{Mwe}$ ) lead to high consumption of electricity. The process water consumption was the highest, compared to case 1 and 2, because of the water to send to water electrolysis (about 2.2 $\mathrm{t} / \mathrm{h})$.

Table 4. Main process results

\begin{tabular}{cccc}
\hline Case & 1 & 2 & 3 \\
\hline Bio-syngas from BG $(\mathrm{t} / \mathrm{h})$ & 2 & 0 & 0 \\
Pure oxygen to gasification $(\mathrm{kg} / \mathrm{h})$ & 584 & 0 & 0 \\
Steam to gasification $(\mathrm{kg} / \mathrm{h})$ & 824 & 0 & 0 \\
Captured $\mathrm{CO}_{2}$ to methanol $(\mathrm{t} / \mathrm{h})$ & 0 & 1.3 & 3.2 \\
Pure hydrogen to methanol $(\mathrm{t} / \mathrm{h})$ & 0 & 0 & 0.24 \\
$\mathrm{R}$ & 2.01 & 2.05 & 2.06 \\
MeOH production $(\mathrm{t} / \mathrm{h})$ & 3.06 & 2.28 & 3.39 \\
Purge ratio $(\%)$ & 4 & 7 & 6 \\
Electricity consumption $(\mathrm{Mwe})$ & 4.4 & 4.0 & 5.4 \\
Process water consumption $(\mathrm{t} / \mathrm{h})$ & 6.8 & 5.9 & 8.1 \\
\hline
\end{tabular}

\section{DISCUSSION}

As reported in previous sections, three alternative cases for bio-methanol production were assessed via computer-aided simulation. Results showed that an AD plant able to process about $10 \mathrm{t} / \mathrm{h}$ of OFMSW might be integrated with a gasification unit to produce bio-methanol. In this case, both waste and biomass may be used with an OFMSW/biomass weight ratio of about $5: 1$. The gasification of biomass by using oxygen/steam as gasification agents allows obtaining a syngas mixture useable for the process, due to low nitrogen content. Air-based gasification would be not suitable for such kind of integration. Because the high pressures requested by methanol synthesis, high compression power and large equipment volumes would be needed due to nitrogen presence. On the other hand, oxygen/steam-based gasification is not a well-known technology and several aspects are still under debate such as temperature control, optimal reactor configuration and so on. Furthermore, the gas stream produced by gasification has to be upgraded in order to obtain a clean syngas for catalysis. Although this aspect was not deeply considered in this work, there are several technologies already at the state of the art that can be used for proper gas cleaning [30]. As reported in Table 5, the process proposed in Case 1 is a characterized of $\mathrm{CO}_{2}$ emission as low as about $2 \mathrm{ktCO}_{2} \mathrm{eq} / \mathrm{y}$ mainly related to the utilization of biomass as feedstock that is assumed to able to absorb about $20 \mathrm{ktCO}_{2} \mathrm{eq} / \mathrm{y}$. The last value may be used as a trade-off value for assessing the type of biomass to be used in the process. When biomass is not used as co-feedstock, the equivalent emission of $\mathrm{CO}_{2}$ strongly increases, although some of the carbon dioxide produced during the anaerobic digestion process is reused for methanol synthesis. In particular, when Case 2 is considered, only $9 \mathrm{kt}_{\mathrm{CO} 2} / \mathrm{y}$ may be used for methanol synthesis.

No significant technological challenges are implied in the process configuration of Case 2 . In the last case, all the $\mathrm{CO}_{2}$ produced from anaerobic digestion plant is used for methanol production but hydrogen has to be produced via water 
electrolysis by using renewable energy.

Table 5. Main environmental results $\left(\mathrm{ktCO}_{2} \mathrm{eq} / \mathrm{y}\right)$

\begin{tabular}{cccc}
\hline Case & 1 & 2 & 3 \\
\hline OFMSW & -120 & -120 & -120 \\
Digestate & 60 & 60 & 60 \\
Flue gas & 18 & 18 & 19 \\
Wastewater & 18 & 17 & 21 \\
$\mathrm{CO}_{2}$ from fermentation & 24 & 15 & 0 \\
Electricity & 20 & 18 & 24 \\
Biomass & -20 & 0 & 0 \\
Pure oxygen & 2 & 0 & 0 \\
Pure hydrogen & 0 & 0 & 4 \\
Total & 2 & 9 & 9 \\
\hline
\end{tabular}

The $\mathrm{CO}_{2}$ emission values reported in Figure 8 show that all of the investigated cases may be considered an alternative to the traditional process for methanol synthesis from natural gas. In particular, when biomass is used as co-feedstock, the $\mathrm{CO}_{2}$ emitted strongly reduced, even if such aspect depends on the type of biomass used for gasification.

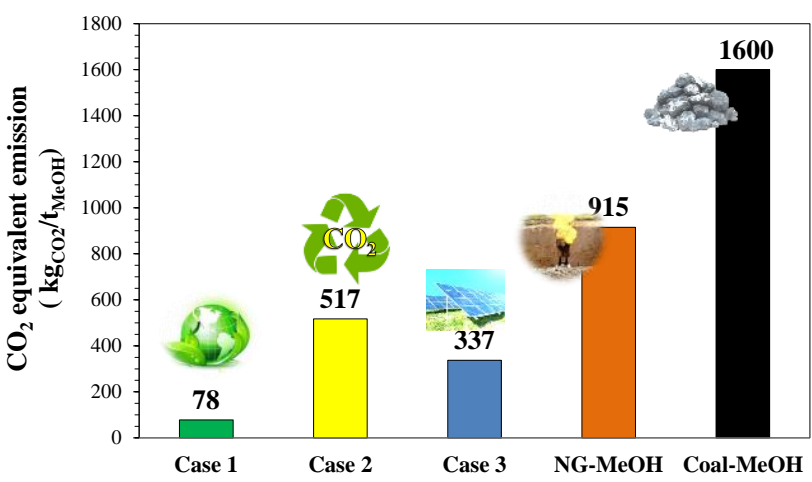

Figure 8. Comparison in terms of environmental impact of investigated cases

Other technical aspects should be taken into account.

For instance, the hydrogen production methods via water splitting by utilization of solar energy may be carried out by photovoltaic, solar thermal energy, photo-electrolysis and bio-photolysis [36]. The utilization of photovoltaic panel for the production of hydrogen from water is a well-known technology; currently, a photo-converter efficiency is higher than $20 \%$ while the efficiency of actual electrolysers is about $80 \%$. In that sense, different types of electrolysers may be used such as PEM, alkaline and solide oxide devices. Protons exchange membranes (PEM) consists of two electrodes and an electrolyte. Demineralized water is fed to the anode when protons and oxygen molecules are formed. The oxygen is separated from protons that are transferred through a membrane to the cathode where hydrogen is formed.For PEM, noble metals membrane (e.g. Pt-based modules) are usually adopted. Furthermore, the utilization of a solid pomymer electrolyte allows to have a compact design with high current density and able to operate also at high pressure.

Alkaline electrolysers uses an alkaline aqueous solution of potassium or sodium hydroxide. Unlike PEM devices, in alkaline cell water is fed to the cathode where hydrogen is directly produced by receiving electrons from external circuit (e.g. PV plant). Although less expensive than PEM system, alkaline electrolysers have several issues mainly related to leakage and low current density that cause a lower hydrogen production.

Solid oxide electrolyser cell is an emerging technology that is gaining a growing interest for hydrogen production [37]. In this device, water is fed to the cathode were hydrogen and oxygen ions are formed. Such oxygen ions are converted to oxygen molecules at the anode. Solid oxide cell requires high operating temperature (e.g. about $1000{ }^{\circ} \mathrm{C}$ ) and therefore the electrical energy for electrolysis process reduces causing a beneficial impact on the hydrogen cost.

Moreover, by using Carbon Capture and Storage (CCS) processes, it is possible to obtain $\mathrm{CO}_{2}$-equivalent emissions equal to or lower than zero [38]. By the capture of $\mathrm{CO}_{2}$ from biogas upgrading process, flue gas of the purge gas combustion, the corresponding emissions of table 5 can be set to zero. This setting makes about equal to/lower than zero the total emission of the plant and, consequently, negative the final value of specific $\left(\mathrm{kg}_{\mathrm{CO} 2 \mathrm{eq}} / \mathrm{t}_{\mathrm{MeOH}}\right)$ emission of biomethanol. To carry out CCS processes very high investment costs are necessary (compression + storage of $\mathrm{CO}_{2}$ ) and, probably, the economic convenience of the plant isn't sufficient for its realization.

\section{CONCLUSIONS}

In this work, different process configurations for biomethanol synthesis have been simulated and discussed. From an environmental point of view, methanol may be produced starting from OFMSW, via anaerobic digestion followed by steam reforming of bio-methane for producing syngas. These systems may be integrated with biomass gasification, carbon dioxide capturing and hydrogen production, to reduce the $\mathrm{CO}_{2}$ footprint. Obtained results in terms of carbon dioxide equivalent emission showed that all of the investigated cases might be considered alternative to the traditional processes for methanol production starting from either natural gas or coal. However the technologies selected for the three selected cases strongly differ in terms of technological maturity and related costs. Case 2 offers some more advantages with respect to the other scenarios: it is less complex in terms of technological platform, even if it produced higher $\mathrm{CO}_{2}$ emissions. A more detailed investigation, either technological and economic, is necessary to get a more reliable assessment of the more profitable case.

\section{REFERENCES}

[1] Giuliano, A., Catizzone, E., Barisano, D., Nanna, F., Villone, A., De Bari, I., Cornacchia, G., Braccio, G. (2019). Techno-environmental assessment for a biomethanol integrated plant using anaerobic digestion of OFMSW, carbon capture and biomass gasification. Tecnica Italiana - Italial Journal of Engineering Science. 6(2-4): 263-269. https://doi.org/10.18280/ti-ijes.632421

[2] Olah, G.A. (2005). Beyond oil and gas: The methanol economy. Angew. Chem. Int. Ed., 44(18): 2636-2639. https://doi.org/10.1002/anie.200462121

[3] Tian, P., Wei, Y., Ye, M., Liu, Z. (2015). Methanol to Olefins (MTO): From fundamentals to commercialization. ACS Catal., 5(3): 1922-1938. https://doi.org/10.1021/acscatal.5b00007 
[4] Catizzone, E., Bonura, G., Migliori, M., Frusteri, F., Giordano, G. (2018). $\mathrm{CO}_{2}$ recycling to dimethyl ether: state-of-the-art and perspectives. Molecules, 23(1): 3158. https://doi.org/10.3390/molecules23010031

[5] Catizzone, E., Migliori, M., Purita, A., Giordano, G. (2019). Ferrierite vs. $\gamma-\mathrm{Al}_{2} \mathrm{O}_{3}$ : The superiority of zeolites in terms of water-resistance in vapour-phase dehydration of methanol to dimethyl ether. J. Energ. Chem., 30: 162-169.

https://doi.org/10.1016/j.jechem.2018.05.004

[6] Bonura G., Migliori, M., Frusteri, L., Cannilla, C., Catizzone, E., Giordano, G., Frusteri, F. (2018) Acidity control of zeolite functionality on activity and stability of hybrid catalysts during $\mathrm{DME}$ production via $\mathrm{CO}_{2}$ hydrogenation. J. $\mathrm{CO}_{2} \quad$ Util., 24: 398-406. https://doi.org/10.1016/j.jcou.2018.01.028

[7] Catizzone, E., Deale, S.V., Bianco, M., Di Michele, A., Aloise, A., Migliori, M., Valtchev, V., Giordano, G. (2018). Catalytic application of ferrierite nanocrystals in vapour-phase dehydration of methanol to dimethyl ether. Appl. Catal. B: Env., 243: 273-282. https://doi.org/10.1016/j.apcatb.2018.10.060

[8] Giuliano, A., Poletto, M., Barletta, D. (2015). Process design of a multi-product lignocellulosic biorefinery Comp. Aided Chem. Eng., 37: 1313-1318. https://doi.org/10.1016/B978-0-444-63577-8.50064-4

[9] Sofia, D., Giuliano, A., Poletto, M., Barletta, D. (2015) Techno-economic analysis of power and hydrogen coproduction by an IGCC plant with $\mathrm{CO}_{2}$ capture based on membrane technology. Comp. Aided Chem. Eng., + 37: 1373-1378. https://doi.org/10.1016/B978-0-44463577-8.50074-7

[10] Giuliano, A., Poletto, M., Barletta, D. (2018). Pure hydrogen co-production by membrane technology in an IGCC power plant with carbon capture. Int. J. Hydrogen Energ., $\quad 43(41)$ : https://doi.org/10.1016/j.ijhydene.2018.08.112

[11] Giuliano, A., Cerulli, R., Poletto, M., Raiconi, G., Barletta, D. (2016). Process pathways optimization for a lignocellulosic Biorefinery production levulinic acid, succinic acid, and ethanol. Ind. Eng. Chem. Res., 55(40): 10699-10717. https://doi.org/10.1021/acs.iecr.6b01454

[12] Dincer, I. (2000). Renewable energy and sustainable development: A crucial review. Renew. Sust. Energ. Rev., 4(2): 157-175. https://doi.org/10.1016/S13640321(99)00011-8

[13] Panwar, N.L., Kaushik, S.C., Kothari, S. (2011). Role of renewable energy sources in environmental protection: A review. Renew. Sust. Energ. Rev., 15(3): 1513-1524. https://doi.org/10.1016/j.rser.2010.11.037

[14] Salvi, B.L., Subramanian, K.A., Panwar, N.L. (2013). Alternative fuels for transportation vehicles: A technical review. Renew. Sust. Energ. Rev., 25: 404-419. https://doi.org/10.1016/j.rser.2013.04.017

[15] Dusselier, M., Mascal, M., Sels, B.F. (2014). Top chemical opportunities from carbohydrate biomass: A chemist's view of the Biorefinery. Top. Curr. Chem., 353: 1-40. https://doi.org/10.1007/128_2014_544

[16] Giuliano, A., Barletta, D., De Bari, I., Poletto, M. (2018). Techno-economic assessment of a lignocellulosic Biorefinery co-producing ethanol and xylitol or furfural. Comp. Aid. Chem. Eng., 43: 585-590. https://doi.org/10.1016/B978-0-444-64235-6.50105-4

[17] Sutton, D., Kelleher, B., Ross, J.R.H. (2001). Review n literature on catalysts for biomass gasification. Fuel Process. $\quad$ Technol., 73(3): 155-173. https://doi.org/10.1016/S0378-3820(01)00208-9

[18] Saxena, R.C., Adhikari, D.K., Goyal, H.B. (2000). Biomass-based energy fuel through biochemical routes: A review. Renew. Sust. Energ. Rev., 13(1): 167-178. https://doi.org/10.1016/j.rser.2007.07.011

[19] Gunaseelan, V.N. (1997). Anaerobic digestion of biomass for methane production: A review. Biomass Bioenerg., 13(1-2): 83-114. https://doi.org/10.1016/S0961-9534(97)00020-2

[20] Mao, C., Feng, Y., Wang, X., Ren, G. (2015). Review on research achievements of biogas from anaerobic digestion. Renew. Sust. Energ. Rev., 45: 540-555. https://doi.org/10.1016/j.rser.2015.02.032

[21] Miltner, M., Makaruk, A., Harasek, M. (2017). Review on available biogas upgrading technologies and innovations towards advanced solutions. J. Clean. Prod., 161: $1329-1337$ https://doi.org/10.1016/j.jclepro.2017.06.045

[22] Dincer, I., Acar, C. (2015). Review and evaluation of hydrogen production methods for better sustainability. Int. J. Hydrogen Energ., 40(34): 11094-11111. https://doi.org/10.1016/j.ijhydene.2014.12.035

[23] Perathoner, S., Centi, G. (2014). $\mathrm{CO}_{2}$ recycling: A key strategy to introduce green energy in the chemical production chain. Chem Sus Chem, 7(5): 1274-1282. https://doi.org/10.1002/cssc.201300926

[24] Quadrelli, E.A., Centi, G., Duplan, J.L., Perathoner, S. (2011). Carbon dioxide recycling: Emerging large-scale technologies with industrial potential. Chem Sus Chem, 4(9):

1194-1215. https://doi.org/10.1002/cssc.201100473

[25] Migliori, M., Catizzone, E., Giordano, G., Le Pera, A., Sellaro, M., Lista., A., Zanardi, G., Zoia, L. (2019). Pilot plant data assessment in anaerobic digestion of organic fraction of municipal waste solids. Processes, 7(1): 54-63. https://doi.org/10.3390/pr7010054

[26] Li, Y., Park, S.Y., Zhu, J. (2011). Solid-state anaerobic digestion for methane production from organic waste. Renew. Sust. Energ. Rev., 15(1): 821-826. https://doi.org/10.1016/j.rser.2010.07.042

[27] Barisano, D., Canneto, G., Nanna, F., Alvino, E., Pinto, G., Villone, A., Carnevale, M., Valerio, V. (2016). Steam/oxygen biomass gasification at pilot scale in a $\mathrm{n}$ internally circulating bubbling fluidized bed reactor. Fuel Process. Technol., 141: 74-81. https://doi.org/10.1016/j.fuproc.2015.06.008

[28] Gurgel da Silva, A.R., Giuliano, A., Errico, M., Rong, B.G., Barletta, D. (2019). Economic value and environmental impact analysis of lignocellulosic ethanol production: assessment of different pretreatment processes. Clean Technol. Environ. Policy, 21(3): 637654. https://doi.org/10.1007/s10098-018-01663-z

[29] Galanopoulos, C., Odierna, A., Barletta, D., Zondervan, E. (2017). Design of a wheat straw supply chain network in Lower Saxony, Germany through optimization. Comput. Aided Chem. Eng., 40: 871-876. https://doi.org/10.1016/B978-0-444-63965-3.50147-1

[30] Perez, J., De Andres, M. J., Lumbreras, J., Rodriguez, E. (2018). Evaluating carbon footprint of municipal solid waste treatment: Methodological proposal and application to a case study. J. Clean. Prod. 205:419-431. https://doi.org/10.1016/j.jclepro.2018.09.103 
[31] Vita, A., Italiano, C., Previtali, D., Fabiano, C., Palella, A., Freni, F., Bozzano, G., Pino, L., Manenti, F. (2018). Methanol synthesis from biogas: a thermodynamic analysis. Renew. Energ., 18: 673-684. https://doi.org/10.1016/j.renene.2017.11.029

[32] Sun, Q., Li, H., Yan, J., Liu, L., Yu, Z., Yu, X. (2015). Selection of appropriate biogas upgrading technology-a review of biogas cleaning, upgrading and utilisation Renew. Sus. Energ. Rev., 51: 521-532. https://doi.org/10.1016/j.rser.2015.06.029

[33] Alsultanny, Y.A., Al-Shammari, N. (2014). Oxygen specific power consumption comparison for air separation units. Eng. J., 18(2): 67-80. https://doi.org/10.4186/ej.2014.18.2.67

[34] Bareiß, K., de la Rua, C., Möckl, M., Hamacher, T. (2019). Life cycle assessment of hydrogen from proton exchange membrane water electrolysis in future energy systems. Appl. Energ., 327: 862-872. https://doi.org/10.1016/j.apenergy.2019.01.001
[35] Li, J., Ma, X., Liu, H., Zhang, X. (2018). Life cycle assessment and economic analysis of methanol production from coke oven gas compared with coal and natural gas routes. J. Clean. Prod., 185: 299-308. https://doi.org/10.1016/j.jclepro.2018.02.100

[36] Tributsch, H. (2018). Photovoltaic hydrogen generation. Int. J. Hydrog. Energ., 33: 5911-5930. https://doi.org/10.1016/j.ijhydene.2008.08.017

[37] Alayi, R., Nemati, R., Shamel, A., Kasaeian, A., Sarkaleh, M. K., Ahmadi, M. H. (2019). Energetic and Exergetic analysis hybrid solid oxide fuel cell systems and gas turbine (SOFC-GT). Mathem. Modell. Eng. Prob., 6: 263-270. https://doi.org/10.18280/mmep.060214

[38] Fichera, A., Volpe, R., Utili, V.O. (2018). A tehncoeconomic and environmental analysis for capture capture and storage in Italian power plants. Modell. Measur. Control B, 87: 167-171. https://doi.org/10.18280/mmc_b. 870308 